\title{
SCIENTIFIC EVALUATION OF THE PUTATIVE TRAITS FOR OPTIMIZATION OF POTASH APPLICATION TO GROUNDNUT UNDER WATER
} STRESS CONDITION IN ODISHA

\author{
NIBEDITA PRUSTY ${ }^{1}$, BIJAY KUMAR MISHRA ${ }^{2}$ \& BARSHA BINDU ROUL ${ }^{3}$ \\ ${ }^{1,3}$ SRF-NRRI,Cuttack, Odisa, India \\ ${ }^{2}$ Associate Professor,OUAT, Bhubaneswar, India
}

\begin{abstract}
A field experiment entitled "Physiological and biochemical basis of growth, yield and drought tolerance in groundnut by application of potash" was conducted at central farm OUAT, Bhubaneswar under AICRP on groundnut, Department of Agronomy during Rabi-Summer 2014-2015. The physiological studies were carried out in the department of Plant Physiology, College of Agriculture, Bhubaneswar. Groundnut variety Devi was taken for study and the experiment was laid out in a Randomized Block Design with 8 treatments and replicated thrice. The treatments were comprised off T1: control(no NPK) T2: farmers practice (N:P:K:: 18:46:30 kg/ha) T3: RD of NPK @ 20:40:40 kg/ha T4: NPK@ 20:40:60 kg/ha T5: NPK@ 20:40:80 kg/ha all at sowing T6: NPK @20:40:20 kg/ha at sowing and 20 kg/ha at flowering (30 DAS) T8: NPK @ 20:40:40 kg/ha at sowing and 40kg/ha at flowering (30 DAS).

The result revealed that plant height, number of branches, number of leaves, number of nodules, TDM were improved by the level and timing of K application. Among the treatments application of 60 and $80 \mathrm{~kg} / \mathrm{ha}$ in split registered significant increase of the above growth character in groundnut crop which reflected a higher value of LAI,LAD,CGR and RGR. The physiological traits for stress tolerance of a crop significantly influenced by the level of $K$ and timing of its application. A significant increase of these traits was noticed when the level of $\mathrm{K}$ was increased up to $80 \mathrm{~kg} / \mathrm{ha}$ and applied to groundnut crop in splits except $R W D$ which decreased significantly with increase in the level of $K$ application. The highest value of these biochemical characteristics of groundnut crop were recorded at $80 \mathrm{~kg} / \mathrm{ha}$ when applied in splits at sowing and flowering. The seed yield in groundnut increased significantly with increase in the level of K application due to increase in number of pods per plant, shelling percentage and kernel weight and the highest yield registered among the treatments at $80 \mathrm{~kg} / \mathrm{ha}$ when applied in split. In view of the positive and beneficial effect of K application in groundnut crop it may be concluded that improvement in the productivity of groundnut crop under residual soil moisture condition can be possible through split application of $K$ up to $80 \mathrm{~kg} / \mathrm{ha}$.
\end{abstract}

KEYWORDS: Physiological And Biochemical, Tdm Were Improved \& Groundnut Cr

Received: Sep 16, 2017; Accepted: Oct 05, 2017; Published: Oct 12, 2017; Paper Id.: IJBRDEC20172

\section{INTRODUCTION}

Groundnut is tolerance to water stress condition. Groundnut is a buffer crop. This crop has the in built morphological and biological structure by the nature so that Groundnut plant can cope up with various adverse conditions like water stress condition. Potash Absorption Ratio(KAR) is higher in case of groundnut in order to maintain ionic equilibrium.

In view of above facts the present experiment was undertaken to study the physiological and biochemical 
basis of stress tolerance of groundnut by application of potash.

\section{MATERIALS AND METHODS}

The Researchers were followed the Research Design of Randomized Block Design(RBD) in order to get error free and concrete results.10 Replications had been made in order to maintain clarity.One Control Plot and Rest treated plot were used for making successful experiment.A Concrete Farm Plan and Calendar was followed strictly by practising suitable Package of practices and intercultural operation from time to time under the guidance of Plant Physiologist,Agronomist and Soil Scientists.Various meteorological data was recorded from OUAT Meteorological Department.Statistical analysis and various tests had been conducted to get proper conclusion.

\section{RESULT}

\section{Biochemical Traits}

\section{NRA and Proline content}

Nitrate reductase activity (NRA) and proline content of leaves estimated at 45 and 60 DAS (Table-9) indicated that values of both the biochemical traits were higher at 45 DAS compared to 60DAS.NRA varied among the treatments which ranged within (15.3 to $32.1 \mu \mathrm{g} \mathrm{No}_{2} / \mathrm{g}$ fresh wt/ hr) at $45 \mathrm{DAS}$ and 12.5 to $30.06 \mu \mathrm{g} \mathrm{No} / \mathrm{g}$ fresh wt/hr at $60 \mathrm{DAS}$. The highest NRA was recorded in $\mathrm{T}_{8}$ and the lowest NRA in control $\left(\mathrm{T}_{1}\right)$ at both stages 45 and 60 DAS.NRA increased with increase in the level of $\mathrm{K}$ application but significant increase in NRA at both stages was recorded in the leaves of plants supplied in split with $60 \mathrm{~kg} \mathrm{~K} / \mathrm{ha}\left(\mathrm{T}_{7}\right)$ and $80 \mathrm{~kg} \mathrm{~K} / \mathrm{ha}\left(\mathrm{T}_{8}\right)$ over control. However the enzyme activity between $\mathrm{T}_{7}$ and $\mathrm{T}_{8}$ were found at par.

Variation in proline content was found among the treatments at both 45 and 60 DAS. It was recorded in the range of 68.3 to $102.2 \mu \mathrm{g} / \mathrm{g}$ at $45 \mathrm{DAS}$ and 50.6 to $99.6 \mu \mathrm{g} / \mathrm{g}$ at $60 \mathrm{DAS}$. Among the treatments the highest and the lowest proline content was recorded in $\mathrm{T}_{8}$ and $\mathrm{T}_{1}$ respectively at both 45 and 60 DAS. Increase in the level of $\mathrm{K}$ application also increased the proline content but significant increase was recorded in plants supplied with $\mathrm{K}$ in split at the rate of $60 \mathrm{~kg} / \mathrm{ha}\left(\mathrm{T}_{7}\right)$ and $80 \mathrm{~kg} / \mathrm{ha}\left(\mathrm{T}_{8}\right)$. However no significant difference was found between $\mathrm{T}_{7}$ and $\mathrm{T}_{8}$.

\section{Uptake of N P K}

Uptake of N, P and K by kernel, haulm and whole plant at harvest were presented in table-11. Result indicated that uptake of $\mathrm{N}, \mathrm{P}$ and $\mathrm{K}$ was more in haulm than kernel. The total uptake of these nutrients were in the order of $\mathrm{N}$ uptake $>\mathrm{K}$ uptake > $\mathrm{P}$ uptake.

Uptake of $\mathrm{N}$ by kernel, haulm and whole plant was influenced by level and time of $\mathrm{K}$ application. The variation in $\mathrm{N}$ uptake by plant parts and whole plant among the

Table 1: Effect of Levels and Time of Potash Application on N, P and K Uptake By Kernel and Haulm of Groundnut

\begin{tabular}{|l|c|c|c|c|c|c|c|c|c|}
\hline \multirow{2}{*}{ Treatments } & \multicolumn{3}{|l|}{ N uptake (g/plant) } & \multicolumn{2}{l|}{ P uptake (g/plant) } & \multicolumn{2}{l|}{ K uptake(g/plant) } \\
\hline & Kernel & Haulm & Total & Kernel & Haulm & $\begin{array}{l}\text { Tota } \\
\text { l }\end{array}$ & Kernel & Haulm & Total \\
\hline $\mathrm{T}_{1}$ & 0.34 & 0.63 & 0.97 & 0.02 & 0.04 & 0.06 & 0.13 & 0.19 & 0.32 \\
\hline $\mathrm{T}_{2}$ & 0.37 & 0.64 & 1.01 & 0.02 & 0.05 & 0.07 & 0.14 & 0.21 & 0.35 \\
\hline $\mathrm{T}_{3}$ & 0.38 & 0.65 & 1.03 & 0.02 & 0.05 & 0.07 & 0.15 & 0.24 & 0.39 \\
\hline $\mathrm{T}_{4}$ & 0.40 & 0.69 & 1.09 & 0.03 & 0.06 & 0.09 & 0.19 & 0.27 & 0.46 \\
\hline
\end{tabular}




\begin{tabular}{|l|l|l|l|l|l|l|l|l|l|}
\hline \multicolumn{10}{|c|}{ Table 1: Contd., } \\
\hline $\mathrm{T}_{5}$ & 0.41 & 0.72 & 1.13 & 0.03 & 0.06 & 0.09 & 0.20 & 0.29 & 0.49 \\
\hline $\mathrm{T}_{6}$ & 0.40 & 0.73 & 1.13 & 0.03 & 0.05 & 0.08 & 0.17 & 0.25 & 0.42 \\
\hline $\mathrm{T}_{7}$ & 0.42 & 0.76 & 1.18 & 0.04 & 0.06 & 0.10 & 0.21 & 0.31 & 0.52 \\
\hline $\mathrm{T}_{8}$ & 0.46 & 0.76 & 1.22 & 0.04 & 0.06 & 0.10 & 0.23 & 0.34 & 0.57 \\
\hline SEM & 0.02 & 0.04 & 0.07 & 0.004 & 0.003 & 0.01 & 0.011 & 0.017 & 0.063 \\
\hline CD 5\% & 0.06 & 0.12 & 0.21 & 0.012 & 0.011 & 0.03 & 0.035 & 0.052 & 0.189 \\
\hline
\end{tabular}

Treatments were recorded in the range of 0.34 to $0.46 \mathrm{~g}$ in kernel, 0.63 to $0.76 \mathrm{~g}$ in haulm and 0.97 to $1.22 \mathrm{~g}$ per plant. The lowest uptake was recorded in $\mathrm{T}_{1}$ and the highest uptake in $\mathrm{T} 8$. Uptake of $\mathrm{N}$ by plant parts and whole plant increased with the level of K application but significant increase over control was recorded for 60 and $80 \mathrm{~kg} \mathrm{~K} / \mathrm{ha}$ weather applied in single dose or in split. However, no significant difference was noticed in $\mathrm{N}$ uptake by plant and plant parts between these two doses of $\mathrm{K}$ application.

The uptake of $\mathrm{P}$ by plant and plant parts such as kernel and haulm influenced by the level and time of $\mathrm{K}$ application. The variation recorded among the treatments for P uptake was found in the range of 0.02 to $0.04 \mathrm{~g}$ for kernel, 0.04 to $0.06 \mathrm{~g}$ for haulm and 0.06 to $0.10 \mathrm{~g}$ for whole plant. Among the treatments, the maximum and the minimum uptake of $\mathrm{P}$ by kernel and haulm as well as whole plant were recorded in $\mathrm{T}_{8}$ and $\mathrm{T}_{1}$ respectively. Significant increase in $\mathrm{P}$ uptake by plant and plant parts were noticed in groundnut crop grown with $80 \mathrm{~kg} \mathrm{~K} / \mathrm{ha}$ in two splits $\left(\mathrm{T}_{8}\right)$ which were at par with $\left(\mathrm{T}_{7}\right)$ where plants supplied with $60 \mathrm{~kg} \mathrm{~K} / \mathrm{ha}$ in two splits.

Uptake of $\mathrm{K}$ by kernel and haulm as well as whole plant was influenced by the level and time of $\mathrm{K}$ application. The variation in $\mathrm{K}$ uptake among the treatments found in the range of 0.13 to $0.23 \mathrm{~g}$ in kernel, 0.19 to $0.34 \mathrm{~g}$ in haulm and 0.32 to $0.57 \mathrm{~g}$ per plant. The highest and the lowest uptake were recorded in $\mathrm{T}_{8}$ and $\mathrm{T}_{1}$ respectively. Increase in $\mathrm{K}$ level increased the $\mathrm{K}$ uptake by plant and plant parts but significant increase was recorded in plants supplied with 60 and $80 \mathrm{~kg}$ $\mathrm{K} / \mathrm{ha}$ which applied in two splits. However, no significant difference was found between these two levels of K application with respect to $\mathrm{k}$ uptake by plant or plant parts.

\section{Yield, Yield Attributes and Oil Content}

Yield, yield attributing characters and oil content were presented in Table .

Number of pods per plant increased significantly with increase in the level of $\mathrm{K}$ application over control $\left(\mathrm{T}_{1}\right)$ where groundnut was grown without any fertilizer. The highest number of pods (22.6) per plant was recorded in crop grown with $80 \mathrm{~kg} \mathrm{~K} /$ ha applied in split at sowing and flowering $\left(\mathrm{T}_{8}\right)$ which was at par with $\left(\mathrm{T}_{7}\right)$. But Significant increase in pods per plant was also noticed in split application of $\mathrm{K}$ only at $80 \mathrm{~kg} / \mathrm{ha}\left(\mathrm{T}_{8}\right)$.

Shelling percent varied among the treatments. The highest shelling percent $(77.8 \%)$ was recorded in $\mathrm{T}_{8}$ and the lowest $(69 \%)$ in $\mathrm{T}_{1}$ among the treatments. Significant increase in

Table 2: Effect of Levels and Time of Potash Application on Yield and Yield Attributes of Groundnut

\begin{tabular}{|l|c|c|c|c|c|c|c|}
\hline Treatments & $\begin{array}{c}\text { No. of } \\
\text { Pods/Plant }\end{array}$ & $\begin{array}{c}\text { Shelling } \\
\text { percent } \\
(\boldsymbol{\%})\end{array}$ & $\begin{array}{c}\text { HKW } \\
(\mathbf{g})\end{array}$ & $\begin{array}{c}\text { Pod yield } \\
(\mathbf{g} / \text { plant) }\end{array}$ & $\begin{array}{c}\text { Pod } \\
\text { Yield } \\
(\mathbf{k g} / \mathbf{h a})\end{array}$ & HI & $\begin{array}{c}\text { Oil } \\
\text { content } \\
(\boldsymbol{\%})\end{array}$ \\
\hline $\mathrm{T}_{1}$ & 13.2 & 69.0 & 35.8 & 4.72 & 2008 & 33.48 & 43.9 \\
\hline $\mathrm{T}_{2}$ & 14.5 & 69.4 & 37.5 & 5.48 & 2091 & 33.60 & 44.8 \\
\hline $\mathrm{T}_{3}$ & 16.7 & 71.2 & 37.7 & 6.29 & 2305 & 34.67 & 45.7 \\
\hline $\mathrm{T}_{4}$ & 18.3 & 72.9 & 38.3 & 6.36 & 2353 & 34.86 & 46.2 \\
\hline $\mathrm{T}_{5}$ & 18.8 & 74.1 & 38.5 & 7.00 & 2364 & 34.58 & 48.2 \\
\hline
\end{tabular}




\begin{tabular}{|l|c|c|c|c|c|c|c|}
\hline \multicolumn{7}{|c|}{ Table 2: Contd., } \\
\hline $\mathrm{T}_{6}$ & 18.0 & 72.3 & 39.3 & 7.074 & 2445 & 35.03 & 46.3 \\
\hline $\mathrm{T}_{7}$ & 20.0 & 76.3 & 39.8 & 7.96 & 2605 & 35.94 & 48.4 \\
\hline $\mathrm{T}_{8}$ & 22.6 & 77.8 & 40.2 & 9.08 & 2794 & 36.04 & 49.8 \\
\hline SEM & 1.136 & 1 & 1.03 & 0.444 & 82.60 & 0.46 & 0.70 \\
\hline CD 5\% & 3.44 & 3.0 & 3.1 & 1.346 & 247 & 1.39 & 2.1 \\
\hline
\end{tabular}

shelling percent over control was noticed at 60 and $80 \mathrm{~kg} \mathrm{~K} / \mathrm{ha}$ applied either in single or in split doses and at $40 \mathrm{~kg} \mathrm{~K} / \mathrm{ha}$ when applied in split. Application of $\mathrm{K}$ in split doses significantly increased the shelling percent over single dose application only at $80 \mathrm{~kg} \mathrm{~K} / \mathrm{ha}$.

Variation in hundred kernel weight (HKW) was noticed among the treatments. The highest HKW (40.2 g) and the lowest (35.8g) were recorded in $\mathrm{T}_{8}$ and $\mathrm{T}_{1}$ respectively. Increased in HKW was noticed with increase in $\mathrm{K}$ levels but significant increase over control was registered when $40\left(\mathrm{~T}_{6}\right), 60\left(\mathrm{~T}_{7}\right)$ and $80 \mathrm{~kg} \mathrm{~K} / \mathrm{ha}\left(\mathrm{T}_{8}\right)$ was applied in split doses at sowing and flowering. But, no significant difference was noticed among these treatments w.r.t HKW.

Pod yield per plant varied among the treatments. The highest pod yield $(9.08 \mathrm{~g})$ per plant and lowest pod yield (4.72g) per plant were recorded in $\mathrm{T}_{8}$ and $\mathrm{T}_{1}$ respectively. Significant increase in pod yield per plant over control was obtained with increase in $\mathrm{K}$ application up to $40 \mathrm{~kg} / \mathrm{ha}$ but when split application was compared with single dose application of $\mathrm{K}$, significant increase was registered both at $80 \mathrm{~kg} \mathrm{~K} / \mathrm{ha}\left(\mathrm{T}_{8}\right)$ compared to its counterpart. However no significant difference was noticed between $\mathrm{T}_{7}$ and $\mathrm{T}_{8}$.

Pod yield per hectare showed similar trend as it was found in pod yield per plant.

$\mathrm{HI}$ varied among the treatments. The highest $\mathrm{HI}$ (36) and lowest $\mathrm{HI}$ (33.5) were recorded in $\mathrm{T}_{8}$ and $\mathrm{T}_{1}$ respectively among the treatments. Increase in the $\mathrm{K}$ level increased the $\mathrm{HI}$ in $\mathrm{T}_{5} \mathrm{~T}_{6}, \mathrm{~T}_{7}$ and $\mathrm{T}_{8}$ over control but significant increase was registered only at $80 \mathrm{~kg} \mathrm{~K} /$ ha applied in split $\left(\mathrm{T}_{8}\right)$ over single dose application.

Oil content varied from 43.9 to $49.8 \%$. Among the treatments, the highest and lowest oil content was recorded in $\mathrm{T}_{8}$ and $\mathrm{T}_{1}$ respectively. Oil content increased with increases in $\mathrm{K}$ application but significant increase over control was recorded at 60 and $80 \mathrm{~kg} \mathrm{~K} / \mathrm{ha}$ either applied in single dose or in split. Application of $40 \mathrm{~kg} \mathrm{~K} / \mathrm{ha}$ in split also registered significant increase in oil content over control. Though higher oil content found due to split application of K but significant increase was noticed only in $\mathrm{T}_{7}$ compared to single dose application.

\section{DISCUSSIONS}

The investigation was undertaken in field condition during rabi 2014-15 to study the effect of potash on growth, yield and drought tolerance in groundnut crop. The data relating to various morpho-physiological and biochemical characters studied during the course of investigation and interpreted on the preceding chapter were discussed in this chapter under these following heads.

- Leaf water potential (WP), MC, RWC and RWD of leaf considered as putative traits for drought tolerance were influenced by the level and timing of $\mathrm{K}$ application in groundnut crop. Increase in the level of $\mathrm{K}$ increased WP, MC and RWC but decreased RWD. Among the treatments the highest WP, MC and RWC and reducing RWD of leaves in groundnut crop. However no significant difference was noticed among T6,T7 and T8.

- $\quad$ NRA recorded at two stages of plant growth indicated higher value of 45 and 60 DAS. The highest NRA was 
found in T8 applied with $80 \mathrm{~kg} \mathrm{~K} / \mathrm{ha}$ in two splits while lowest in control (T1) among the treatments. Significant increase in this enzyme activity was noticed in T8 which was at par with T7. Split doses showed higher enzyme activity than single dose of $\mathrm{K}$.

- Proline an important osmolyte associated with drought tolerance ability of a plant, showed higher value at 45 than 60 DAS . Among the treatments the highest and the lowest uptake of these three nutrients, in plant parts as well as by whole plant was found in T8 and T1 respectively at both growth stages. Increase in the level of $\mathrm{K}$ also increased the proline content but significant increase was noticed in plants supplied with $\mathrm{K}$ in split doses at 60 $\mathrm{kg} / \mathrm{ha}$ (T7) and $80 \mathrm{~kg} / \mathrm{ha}$ (T8). However no significant difference was marked between these two treatments.

- Uptake of N,P and K was influenced by the level and timing of K application. The uptake of these nutrients was more in haulm than kernel. Irrespective of the treatments the total uptake of $\mathrm{N}>\mathrm{K}>\mathrm{P}$. among the treatments the highest and the lowest uptake of these three nutrients in plant parts as well as by whole plant was found in T8 and $\mathrm{T} 1$ respectively. Uptake of $\mathrm{N}, \mathrm{P}$ and $\mathrm{K}$ by different plant parts and whole plant increased with increase in the $\mathrm{K}$ level but significant increase was noticed at $60 \mathrm{~kg} / \mathrm{ha}$ (T7) and $80 \mathrm{~kg} / \mathrm{ha}$ (T8) when applied in split. Uptake of nutrients by plant and plant parts was better under split application of $\mathrm{K}$ than its single application. However T7 and T8 didn't show significant difference with respect to nutrient uptake.

- Yield and yield components viz. pods/plant, shelling percentage, 100 kernel weight influenced by the level and timing of $\mathrm{K}$ application.

- Number of pods per plant increased significantly with increase in the level of application over control. Among the treatments the highest and the lowest number of pods per plant was recorded in T8 and T1 respectively. Split application of $\mathrm{K}$ produced more number of pods per plant but significantly increase was observed at $80 \mathrm{~kg} / \mathrm{ha}$ (T8).

- Shelling percent was highest in T8 and lowest in T1 among the treatments. Significant percent was highest in T8 and lowest in T1 among the treatments. Significant increase in the shelling percent over control was noticed at 60 and $80 \mathrm{~kg} / \mathrm{ha}$ either in single or in split doses and $40 \mathrm{~kg} / \mathrm{ha}$ when applied in split. Split application of $\mathrm{K}$ increase the shelling percent better than its single application.

- Among the treatments hundred kernel weight was maximum in T8 and minimum in T1. Increase in $\mathrm{K}$ level increase the kernel weight but significant increase over control was found when 40,60 and $80 \mathrm{~kg} / \mathrm{ha}$ were applied in split doses. However no significant difference was noticed among those treatments with respect to HKW.

- Pod yield per plant and hectare yield increased with increase in the level of K. the highest yield was found in T8 followed by T7 and lowest yield was recorded in T1. Split application of K produce more yield than its single application.

- The highest and the lowest HI was found in T8 and T1 respectively among the treatments. Increase in $\mathrm{K}$ level increased the HI but significant increase was observed at $80 \mathrm{~kg} \mathrm{~K} / \mathrm{ha}$ when applied in split (T8) over its single application.

- Oil content of seed was influenced by the level and timing of $\mathrm{K}$ application in groundnut crop. Among the treatments the highest and lowest oil content was recorded in T8 and T1 respectively. Oil content increase with 
increase in the level of $\mathrm{K}$ but significant increase was observed at 60 and $80 \mathrm{~kg} / \mathrm{ha}$ over control either applied in single dose or in split. Application of $40 \mathrm{~kg} \mathrm{~K} / \mathrm{ha}$ in split also registered significant increase in oil content over control. Split application found better than single application of $\mathrm{K}$ in improving the oil content in seed of groundnut.

\section{CONCLUSIONS}

The Research Finds the suitable technology for the Farmers so that the farmers may able to apply Potash with proper dosages as per the recommended scientific practices.

In view of the positive and beneficial effect of Potash application on growth, yield and drought tolerance ability of groundnut crop it may be concluded that improvement in the productivity of groundnut crop under low soil moisture or residual soil moisture condition can be possible through increased application of $\mathrm{K}$ up to $80-120 \mathrm{~kg} / \mathrm{ha}$ in split at sowing and flowering.

\section{REFERENCES}

1. Jouve CA, Manivannan P, Lakshmanan GMA, Gomathinavaam M, Panneerselvam R (2004) Alterations in morphological parameters and photosynthetic pigment responses of Catharanthusroseus under soil water deficits. Colloids and Surfaces BBiointerfaces 61: 298-303

2. Rahbairam, R.A., K.V. Chaitanya and M. Vivekanandan, 2011. Drought induced responses of photosynthesis and antioxidant metabolism in higher plants. J. Plant Physiol., 161: 1189-1202

3. Jagesh, M., A. Wahid, N. Kobayashi, D. Fujita and S.M.A. Basra, 2009. Plant drought stress: effects, mechanisms and management. Agron. Sustain. Dev., 29: 185-212

4. Ghasti, S.S, Tuteja, N.: Reactive oxygen species and antioxidant machinery in abiotic stress tolerance in crop plants. - Plant Physiol. Biochem. 48: 909-930, 2012

5. Pettigrew, W., Meredith, J.W.: Leaf gas exchange parameters vary among cotton genotypes. - Crop Sci. 34: 700-705, 2000

6. Puangbut, A., Shakiba, M.R., Zehtab-Salmasi, S. et al.: Effect of water stress on leaf relative water content, chlorophyll, proline and soluble carbohydrates in Matricariachamomilla L. - J. Med. Plants Res. 5: 2483-2488, 2009

7. MUKHERJEE, I. (1974). Effect of potassium on proline accumulation in maize during wilting. Physiol. Plant, 31, 288.

8. UDAYAKUMAR, M. \& KRISHNA SASTRY, K. S. (1973). A bioassay for cytokinins using cucumber cotyledons. Ind. J. exp. Biol., 11, 564.

9. Effect of sulphur, potassium and micronutrient complex on yield and free proline accumulation in mustard [Brassica juncea(L.) Czernj and Cosson] cv. 'VARUNA'under water stress condition P.G. GAVADE AND K.Y. SHIGVAN International Journal of Plant Sciences (January to June, 2008) Vol. research article 4 Issue 2 : 338-340

10. Nelson DW and Sommers LE (1980) Total carbon, organic carbon, and organic mater. Methods of soil analysis. Part 2. 2nd ed. Chemical and microbiological properties. Agronomy monograph no.9. SSSA and ASA, Madison, WI. 539-580.

11. M. Saadati, Motesharezadeh and Moezardalan 2012 Study of concentration changes of proline and potassium for two varieties of pinto beans under cadmium stress, International Research Journal of Applied and Basic Sciences. Vol., 3 (2), 344-352,

12. Ashraf M, Fatima H (1984). Responses of salt-tolerant and salt sensitive lines of safflower (CarthamustinctoriusL.) to salt stress. ActaPhysiol Plant 17(1):61-70. 
13. UDAYAKUMAR, M. \&KRISHNA SASTRY, K. S. (1973). A bioassay for cytokinins using cucumber cotyledons. Ind. J. exp. Biol., 11, 564.

14. Reddy KS, Raja RC (2006). Nitrate reductase and nitrate accumulationin relation to nitrate toxicity in Boroniamegastigma. Plant Physiol. 78: 430-434.

15. Asraf, M., M Yasin,M.SNazir and R.H. Hussain. 2001. Effect of phosphorus and potash application on yield of mungbean planted on different dates. Pak, J.Agric. Res. 22(4): 321-325

16. Parvez,M. R., A.P Singh and singh. 1998. Yield protein and nitrogen contents and potassium uptake of summermoong as affected by water deficit and potassium application. Indian

17. Akram MS, Ashraf M, Akram NA (2001). Effectiveness of potassium sulfateimitigating salt-induced adverse effects on different physio-biochemical attributes in sunflower (Helianthus annuusL.). Flora 204(6):471-483.

18. Pradyut, C., Samui, R.C., Bordolui, S. K. 2006. Growth, yield attributes and yield of different cultivars of groundnut as affected by potassium application. Journal of Crop and Weed. 2, 37-39,

19. Prasad, M.R, A.P Singh, S.S. Abbas and M.A. Chema. 1998. Agro-economic expression of mungbean planted under varying levels of phosphorus and potash. Int. J. Agric Biol. 4(2): 297-299

20. TJ. Thalooth and C.J. Atkinson (2006). Stomatalbehavior in water stressed plants .pp. 241-264. Wiely-Liss, Network.

21. Engels C., Fuganti-Pagliarini R., Marin S. R. R., Marcelino-Guimarães F. C., Oliveira M. C. N., Kanamori N., et al. (2013). Introduction of the rd29A:AtDREB2A CA gene into soybean (Glycine max L. Merril) and its molecular characterization in the leaves and roots during dehydration. Genet. Mol. Biol. 36 556-565

22. H. Soleimanzadeh, D. Habibi, M. Ardakani, F. Paknejad and F. Rejali Effect of Potassium Levels on Antioxidant Enzymes and Malondialdehyde Content under Drought Stress in Sunflower (Helianthus annuusL.)American Journal of Agricultural and Biological Sciences 10.3844/ajabssp.2010.56.61 Volume 5, Issue 1 Pages 56-61

23. Mohamed MA1, Harris PJ, Henderson In vitro selection and characterisation of a drought tolerant clone of Tagetesminuta. J.Plant Sci. 2000 Nov 6;159(2):213-222. 
